Published as: Kuckertz, A. \& Wagner, M. (2010) The Influence of Sustainability Orientation on Entrepreneurial Intentions - Investigating the Role of Business Experience, Journal of Business Venturing, 25, 524-539. DOI:10.1016/j.jbusvent.2009.09.001

\title{
The Influence of Sustainability Orientation on Entrepreneurial Intentions - Investigating the Role of Business Experience
}

\section{Abstract}

Do individuals who are concerned by issues of sustainability also exhibit stronger entrepreneurial intentions? Given that existing imperfections in the market create numerous opportunities for entrepreneurship connected with sustainable development, adding individual sustainability orientation to models of entrepreneurial intention could increase their explanatory power. Based on survey data collected from engineering and business students and alumni of three universities, we provide evidence that entering sustainability orientation into the equation is actually meaningful. However, our findings suggest that the positive impact of sustainability orientation vanishes with business experience. Consequently, we suggest measures to nourish an evidently existing potential for sustainable entrepreneurship.

\section{Executive Summary}

The emerging stream of academic literature on sustainable entrepreneurship adds a new dimension to the general promise of entrepreneurship. No longer is entrepreneurship supposed to merely result in economic success: sustainable entrepreneurs manage to the "triple bottom line" by balancing economic health, social equity and environmental resilience through their entrepreneurial behavior. Sustainable entrepreneurship is thus clearly associated with the promise of more traditional concepts of entrepreneurship, but also brings additional potential both for society and the environment.

With this paper we contribute to the emergent stream of literature on this important topic in one particular aspect. Above all, we are interested in individuals who are concerned with environmental and societal issues; individuals who are sustainability oriented and thus could potentially be more interested in supporting initiatives and forming businesses that support the idea of sustainability. In other words, we aim to answer the question of how sustainability orientation and entrepreneurial intentions are related in practice. Our paper, as a relatively rare exception uses large-scale survey data to provide empirical insights into this question. In doing so, and by being rooted in entrepreneurship theory and theorizing on sustainable development, it links debates on entrepreneurship for sustainable development with mainstream theories of entrepreneurship and at the same time provides a balance to the wealth of conceptual models on sustainable entrepreneurship. 
Embedding our empirical analysis in entrepreneurship theory, we hypothesize a positive relationship between an individual's sustainability orientation and entrepreneurial intention. However, based on the literature on organizational legitimacy and empirical findings from research on business ethics, we hypothesize as well that business experience negatively impacts on this relationship. Based on data collected from students and alumni from science and engineering programs plus students from business programs at three universities, we apply ordinal probit models and find support for these hypotheses. Our ordinal probit models suggest that engineering students with a stronger sustainability orientation are more likely to intend to become self-employed. However, this association becomes insignificant when comparing the engineering student sample to the business student sample and an alumni sample. Hence we conclude that sustainability orientation influences entrepreneurial intention, but not for every group of individuals. Business experience apparently destroys the positive relationship between sustainability orientation and entrepreneurial intention and this has important implications for entrepreneurship education and policy.

To nurture sustainable entrepreneurship, we therefore suggest that educators take at least the following measures (ordered by priority). First and foremost, special attention should be paid to master's degree, executive and continuing education programs in order to close the gap apparently opened by business experience. Individuals with business experience participating in such programs are particularly well qualified to implement business models based on opportunities for sustainable entrepreneurship. Such programs should therefore aim to link their entrepreneurship components up more strongly with sustainability-related content, and through that, provide more comprehensive information to experienced students wishing to pursue entrepreneurial opportunities. More systematic education on ways of realizing the entrepreneurial potential related to market imperfections may well enhance participants' perseverance in pursuing sustainability-related entrepreneurial opportunities. Given that one of the largest benefits of entrepreneurial education seems to be not the acquisition of knowledge about certain management instruments but rather entrepreneurial inspiration, we consider it essential to include more cases of successful sustainable entrepreneurship in courses targeting experienced individuals. Moreover, providing a platform in class for entrepreneurs committed to pursuing sustainable business models will also enhance the level of entrepreneurial intention amongst their audiences.

Second, the potential of market imperfections to reveal sustainable entrepreneurial opportunities should be a standard component of every undergraduate curriculum. At the same time, we deem it essential that not only the business student faction but a wider congregation of people concerned about sustainability is awakened to the additional potential brought by sustainable entrepreneurship. Prior research suggests that such individuals show a high propensity to act to achieve their sustainability related goals (for instance, grass-roots-activists affiliated to particular NGOs), but might not yet have considered economic action that would be in line with their sustainability orientation. Also, intervention at the undergraduate level provides a different framing for subsequent business experience and hence could alter its effect on the link studied. 
All in all, our theoretical reasoning and the empirical results presented subsequently indicate that individual sustainability orientation can indeed explain entrepreneurial intention to some degree; our results are thus informative for researchers interested in the antecedents of entrepreneurial intention and can also be utilized to further establish sustainable entrepreneurship as an important sub-field of the entrepreneurship domain.

\section{Introduction}

Entrepreneurship is usually associated with numerous promises. From a policy-makers vantage point, entrepreneurial behavior of economic actors within an economy is supposed to increase the competitiveness of that economy in global markets and potentially creates new employment opportunities. From the perspective of an individual entrepreneur, exploiting entrepreneurial opportunities can be attractive because such opportunities bring with them the promise of a meaningful career and the potential of harvesting superior entrepreneurial rents.

The emerging stream of academic literature on sustainable entrepreneurship ${ }^{1}$ adds a new dimension to this promise. Entrepreneurship for sustainable development is supposed to result in more than economic success. Sustainable entrepreneurs manage to the "triple bottom line" (Elkington, 1997), in other words they balance economic health, social equity and environmental resilience through their entrepreneurial behavior. Sustainable entrepreneurship is thus associated with the promise of more traditional concepts of entrepreneurship, but also has additional potential both for society and the environment. Against this background, the recent upsurge of writing in this field is far from surprising. The topic of entrepreneurship for sustainable development lies at the nexus of innovation, sustainability concerns and entrepreneurship and has emerged as an intensively debated subject moving increasingly from journals focused on environmental management (e.g., Schaltegger, 2002) to mainstream business and entrepreneurship journals (e.g., Cohen and Winn, 2007; Dean and McMullen, 2007). The phenomenon itself, however, is far from being a new one; history provides numerous examples of entrepreneurs pursuing sustainable business models as early as the $19^{\text {th }}$ century (Anderson and Leal, 1997). Yet, due to its emergent character, to date most contributions have naturally remained conceptual or have reported results of case study research (e.g., Schaltegger, 2002). In light of the topic's importance and potential, we believe that it is time to move to the application of more rigorous research designs and that the discussion of sustainable entrepreneurship will benefit from the development of large-scale empirical research projects.

\footnotetext{
${ }^{1}$ As in prior literature (e.g., Dean and McMullen, 2007; Cohen and Winn, 2007; Schaper 2005) we make use of the shorthand term sustainable entrepreneurship even though it would be more precise to refer to entrepreneurship for sustainable development. This is because sustainable entrepreneurship could be understood too narrowly as referring to entrepreneurial activities aimed at creating sustained competitive advantage. In principle, all entrepreneurial activities can foster or hinder sustainable development, which is why we do not talk of sustainable development-related entrepreneurship. When we use the term of sustainable entrepreneurship in the remainder of this paper, we refer only to those entrepreneurial activities, which contribute positively to sustainable development and the objectives derived from it.
} 
It is this gap in the literature that our paper addresses in one important aspect. In particular, we are interested in individuals who are concerned with environmental and societal issues, those who are sustainably oriented and thus could be interested in pursuing initiatives and forming businesses that support the idea of sustainability. In other words, we aim to answer the question of how sustainability orientation and entrepreneurial intentions are related in practice. Could it be that sustainability orientation adds to our understanding of entrepreneurial intentions and if so, what would be the consequences for entrepreneurship policy and entrepreneurial education? Therefore, we analyze the linkages between sustainability orientation amongst university students and their respective entrepreneurial intentions, since with this particular group goes considerable potential for educators to produce future entrepreneurs in environmentally and socially more sustainable fields of enterprise.

To do so, the paper proceeds along the following lines. First, we review the extant literature on sustainable entrepreneurship and entrepreneurial intentions with a specific focus on entrepreneurial education. Based on this literature review we derive two hypotheses that will be tested with empirical data collected from 712 students and alumni from three different universities. We essentially use statistical methods and econometric models well established in the entrepreneurship field to put our hypotheses to a rigorous test. After reporting our results, the findings are discussed together with their implications for entrepreneurship policy and entrepreneurship education.

\section{Theoretical Background}

\subsection{Sustainable entrepreneurship}

Environmental and societal issues today are overabundant. For instance, the potentially negative consequences of global warming are widely accepted, many industrialized countries are experiencing mass unemployment or wrestling with the challenges resulting from an increasingly globalized economy and society. Many of these challenges could be attributed to negative externalities or other phenomena described in the classical economics literature, such as the tragedy of the commons (Hardin, 1968). Sustainable behavior, or in short sustainability, is a paradigm that can function as a reference point for the development of solutions to today's environmental and societal challenges. The Brundtland Commission, brought into being by the United Nations in the early 1980s, defined sustainability as meeting "the needs of the present without compromising the ability of future generations to meet their own needs" (World Commission on Environment and Development, 1987: 54).

One solution to achieve this goal has been, and of course still is, government intervention. However, Coase (1974) in his classic example of the provision of lighthouses for maritime shipping pointed out that in the past the private supply of services has proved possible even in areas that were previously believed to be only serviceable by public authorities. As government intervention does not necessarily need to be the only answer to environmental and societal challenges, the role of private economic actors comes to prominence. Many researchers have therefore explored the general link of overall economic behavior, management and sustainability (e.g., Aragon- 
Correa and Sharma, 2003; Hall and Vredenburg, 2003; Lenox, 2006). From the perspective of entrepreneurship research, researchers have pointed to how concepts of entrepreneurship theory can inform us about sustainable economic behavior. In particular, we will show that the concept of entrepreneurial opportunities (Kirzner, 1985; Venkataraman, 1997; Shane and Venkataraman, 2000) has turned out to be quite fruitful. The reasons for this is that more radical innovation which has the largest potential to contribute to sustainable development oftentimes emerges from entrepreneurial ventures and therefore sustainable entrepreneurship is particularly desirable from a social welfare perspective, as opposed to, for instance, end-of-pipe activities.

The early literature on sustainable entrepreneurship has often dealt exclusively with environmentally oriented entrepreneurship (Staber, 1997; Keogh and Polonsky, 1998; Pastakia, 1998; Isaak 1999; Schaltegger, 2002; Linnanen, 2002; Walley and Taylor 2002; Lehmann et al., 2005; Schaper, 2005) and underlines, for instance, that so-called envirocapitalists "are entrepreneurs using business tools to preserve space, develop wildlife habitat, save endangered species, and generally improve environmental quality" (Anderson and Leal, 1997: 3). Other contributions to the field focus primarily on the social aspect of sustainable entrepreneurship (Brinckerhoff, 2000; Borzaga and Solari, 2001; Prahalad and Hammond, 2002; Mair et al., 2005; Prahalad, 2005; Prahalad 2006; Bright et al., 2006; Milstein et al., 2006; Desa and Kotha, 2006; Nicholls, 2006). For example, some authors propose typologies of eco-entrepreneurship (e.g., Schaltegger 2002), distinguishing it from other forms of corporate environmental management activity. Similarly, Isaak (1999) separates incumbent firms that become incrementally more environmentally concerned, from entrants providing environmentally benign products and services using environmentally friendly processes from the inception of their business operations. Writings in the social entrepreneurship literature, on the other hand, focus primarily on how to provide club goods to members or on how to provide access to innovation for specific deprived market segments (Desa and Kotha, 2006), especially in the context of bottom-of-the-pyramid innovation in emerging markets and developing economies (Prahalad, 2005; Prahalad, 2006). Moreover, the social entrepreneurship literature is also concerned with case analyses of successful nonprofit social ventures (e.g., Desa and Kotha, 2006) and the effect of globalization on opportunities for social entrepreneurship (Zahra et al., 2008). What is notable about these classifications (e.g., Linnanen, 2002; Walley and Taylor 2002) is, however, the absence of the dimension of innovativeness (e.g., radical versus incremental or original versus imitation) which seems to be of considerable relevance for entrepreneurial rents as well as opportunity realization. The recent literature on sustainable entrepreneurship has consequently attempted to integrate environmental and social aspects (Larson, 2000; Kyrö, 2001; Cohen, 2006), and simultaneously links the process of entrepreneurship (Bhave, 1997) to the concept of opportunity recognition that is in numerous respects closely related to innovativeness (Buttner and Gryskiewicz, 1993).

For instance, building on Venkataraman's (1997) definition, Cohen and Winn define research on sustainable entrepreneurship as the investigation of "how opportunities to bring into existence 'future' goods and services are discovered, created, and exploited, by whom, and with what economic, psychological, social, and environmental 
consequences" (2007: 35; italics in original). Dean and McMullen take up a similar position; however, they highlight the necessity of adopting a process perspective (Brazeal and Herbert, 1999) with their definition of sustainable entrepreneurship as "the process of discovering, evaluating, and exploiting economic opportunities that are present in market failures which detract from sustainability, including those that are environmentally relevant" (Dean and McMullen, 2007: 58).

Despite clearly defining the field, recent writings have in addition linked sustainable entrepreneurship to market imperfections and in doing so, have provided a much more systematic categorization of entrepreneurial opportunities that simultaneously contribute to sustainable development. Isaak (1999) and Pastakia (1998) mention the reduction of negative (environmental) externalities as a defining criterion for environmentally oriented entrepreneurship. In essence, authors from this school argue that specific market failures are the underlying root cause for entrepreneurial activities aimed at realizing social objectives as well as environmental improvements (Cohen and Winn, 2007; Dean and McMullen, 2007; Cohen et al. 2008) and bring with them considerable economic potential. Some even postulate a correlation between the extent of market failure and the economic promise resulting from the related opportunity to alleviate this market failure (Dean and McMullen, 2007).

The review of extant work reveals that the literature on entrepreneurship for sustainable development has grown quantitatively over time. Whilst it has been published more frequently in mainstream business journals and has become more accommodating qualitatively, it still has not fully integrated the extensive literature on conventional entrepreneurship. In particular, there exists a large theoretical, conceptual and empirical body of work dealing with the factors that determine entrepreneurial behavior and intentions, such as attitudes, education or situational aspects. It is this literature we will link to entrepreneurship for sustainable development in the subsequent paragraphs.

\subsection{Sustainability concerns and entrepreneurial intentions}

The literature review so far suggests that entrepreneurship for sustainable development holds a bold promise, namely, that because entrepreneurial opportunities exist which are caused by market imperfections, individuals will pursue these in the expectation of entrepreneurial rents. However, the literature could also lead one to the conclusion that entrepreneurially minded individuals will pursue exactly those opportunities from which they expect the highest rents to be extractable. The question immediately arises, as to whether the entrepreneurial opportunities that are based on market imperfections are indeed identical to those that promise the highest entrepreneurial rents (Dean and McMullen, 2007). One could argue that given the large number of market imperfections still existing with regard to the environment and social conditions, based on revealed preferences, the answer is no. More specifically, this holds true for a number of environmental fields. For example, the case of energy efficiency perfectly illustrates how inefficiencies persist, even though their removal would be profitable - yet not profitable enough to be preferred in the light of other investment opportunities with higher returns (e.g., Jaffe and Stavins, 1994; Sanstad and Howarth, 1994). However, whilst these energy saving opportunities are an example which is not likely to be considered by an 
individual focusing on maximizing economic rents, such opportunities with great(er) sustainability benefits (and at least a certain level of profitability) could be of interest for a potential entrepreneur oriented towards sustainability. For such sustainable development-oriented entrepreneurs (defined more generally as those individuals with entrepreneurial intentions who aim to manage a "triple bottom line"), harvesting entrepreneurial rents is most likely not the only aim and this at least in theory leaves open the possibility of 'satisficing' behavior (Simon, 1956: 129) implying pursuance of opportunities with more limited profitability yet higher sustainability benefits. Even in a utility maximization framework such behavior of entrepreneurs could be explained in that non-monetary benefits could be a significant element of an entrepreneur's utility function (Pfeiffer and Reize, 2000). For example, existence and option values are wellestablished non-use values in environmental cost-benefit analysis (Willis, 1989; Hanley and Spash, 1992). Hence knowing that for instance pursuance of a specific entrepreneurial opportunity could help reduce carbon dioxide emissions and in turn assist in preserving tropical rainforests, could lead to a higher overall utility to a sustainable development-oriented entrepreneur than choosing an opportunity that only maximizes the economic rents.

Therefore, with respect to entrepreneurship educators and policy makers, the question of what could be done to foster entrepreneurial intentions, targeted not only at the conventional, but also at opportunities related to sustainable development, is of utmost importance. Given that intentions are the single most important predictor of actual behavior (Ajzen and Fishbein, 1977; Souitaris et al., 2007), studying the antecedents of entrepreneurial intentions especially among students has garnered considerable attention among entrepreneurship researchers recently (e.g., Krueger et al., 2000; Lüthje and Franke, 2003, Souitaris et al., 2007). An early answer to the question of what factors affect entrepreneurial intentions has been offered by the traits approach, in other words, entrepreneurial intentions and behavior were ascribed solely to the personality of the individual (for a recent review of this early literature see Baum et al., 2007). Antecedents such as self-efficacy, risk-taking propensity or optimism were identified (Arabsheibani et al., 2000; Stewart and Roth, 2001; Fraser and Greene, 2006; Rauch and Frese, 2007); however, against the background of many inconsistent findings wide criticism of this approach arose (Gartner, 1988; Keh et al., 2002; Mitchell et al., 2002). As entrepreneurial phenomena occur in different contexts and in close interaction with other individuals and the environment (Robinson et al., 1991), explanations based merely on the personality of the individual produce a somewhat reductionist impression. Consequently, based for instance on the theory of planned behavior (Ajzen, 1991), contextual factors have been integrated into recent models of entrepreneurial intentions (Krueger et al., 2000; Lüthje and Franke, 2003). Lüthje and Franke (2003) are able to show that in the context of entrepreneurship education such contextual factors should be differentiated into perceived barriers to entrepreneurship, and perceived support for entrepreneurship. Souitaris et al. (2007) report similar results, while at the same time they stress the point that inspiration by educators and successful entrepreneurs will result in a higher level of entrepreneurial intention among students.

With respect to sustainable entrepreneurship we propose that it makes sense to add a further variable into the equation, namely an individual's sustainability orientation, given 
that an individual's interests (DiMaggio, 1988) are important to understand the emergence of organizations. The reason for doing so is based on the specific definition of sustainable entrepreneurship suggested by Dean and McMullen (2007) that closely linked existing market imperfections to entrepreneurial opportunities. From a conservative viewpoint, the solution to market imperfections with (potentially) detrimental environmental and social effects would call for intensified government intervention. The advent of more and more non-governmental organizations (NGOs) trying to exert political pressure on policy makers stands in this tradition (Oppenheimer, 2006) - many individuals who are highly involved in questions of sustainability naturally get involved with NGOs holding corresponding views. For instance, empirical research shows that people with deep environmental concerns have a higher desire to express these values by acting according to their values and engaging in voluntary action (Bruyere and Rappe, 2007). If, however, market imperfections are not just issues to be resolved by policy-makers, but are part of an area to be simultaneously associated with entrepreneurial opportunity (Cohen and Winn, 2007; Dean and McMullen, 2007), we have reason to believe that sustainability-oriented individuals will also have a higher propensity to perceive entrepreneurial opportunities resulting from unsustainable economic behavior. This is due to the fact that the perception of specific entrepreneurial opportunities depends on prior individual knowledge (Shane, 2000). Opportunities for sustainable entrepreneurship therefore are not readily observable by everyone or might not even be perceived as opportunities (Zahra et al, 2009). The example of the founder of Ecotricity, a British green energy entrepreneur specializing in wind power, illustrates this aspect. Prior to starting various sustainable ventures, Ecotricity's founder spent many years as a travelling activist and peace campaigner, so, in this particular case, before personal sustainability concerns translated into economic behavior, the personal dedication to a cause was targeted at more traditional kinds of political grassroots activities. The case illustrates that even if not all opportunities for sustainable entrepreneurship (Bennett, 1991; Berle, 1991) are related to superior entrepreneurial rents, sustainability oriented individuals will a) perceive a higher number of such opportunities and b) show a stronger intent to act upon such opportunities, given that these are not only associated with entrepreneurial, but with environmental and/or social rents as well. Accordingly:

H1: There will be a positive relationship between individuals' sustainability orientation and their entrepreneurial intention.

In light of the literature on values and ethical beliefs of students, there are reasons to assume that this positive impact of sustainability orientation on entrepreneurial intention does not hold true in all contexts. Placing students and business people on an experience continuum from comparatively inexperienced (e.g., undergraduate students) to comparatively experienced (e.g., middle managers or entrepreneurs) with respect to their business experience the level of sustainability orientation is likely to decline, and thus its impact on entrepreneurial intention as well (Figure 1). In other words: Business experiences cause the positive influence of sustainability orientation to vanish over time. 
Insert Figure 1 about here

This notion becomes clear in view of two streams of literature. First, empirical studies examining the ethical values and sustainability concerns of students have found that undergraduate business students exhibit less concern for the environment and a lower tendency to behave in an environmentally friendly manner, compared to non-business students (Benton, 1994). At the same time, undergraduate students generally differ from more experienced MBA students, who usually can draw upon considerable work experience, in their perception of ethical beliefs (Parsa and Lankford, 1999) in that the former exhibit a higher tendency to act more ethically. Furthermore, comparing business students and managers from the service sector in terms of their perception of ethics and social responsibility results in significant differences as well; in particular students seem to be more concerned with questions of ecology than managers (Kraft and Singhapakdi, 1991). Placing these four groups (non-business students, undergraduate business students, MBA students, and managers) on the business experience continuum thus apparently goes along with a strong decline in ethical concerns, of which concerns for sustainable development-oriented behavior are a clear sub-category. A similar phenomenon can be observed in the context of environmental and sustainability-related concerns and actions in society at large. For instance, studies regularly conducted on behalf of the German Federal Ministry for the Environment, Nature Conservation and Nuclear Safety (BMU, 1998; BMU, 2000; BMU, 2002) suggest that the larger part of the population has considerable environmental concerns, but only a small minority acts upon them. The reasons that qualitative research provides for this pattern (manifested, for instance, in terms of considering it important to save resources, but not participating in recycling schemes or in terms of citizens feeling that trade should be fair between poorer and richer countries, but not willing to pay a premium for fair trade products) seem quite similar to those explaining experienced business peoples' lower ethical concerns. These results can thus help to shed light on the underlying mechanisms that explain this effect of greater experience (Diekmann and Preisendörfer, 1991). They relate to the increased complexity of action in a social environment, to contradicting demands, to limited cognitive resources and bounded rationality, factors that have also been found to be important in the context of consumer behavior with regard to environmental impacts and as concerns the behavior of employees particularly in smaller firms (Dembkowski and Hamner-Lloyd, 1994; Tilley, 1999).

Second, results from the opportunity recognition stream of the entrepreneurship literature suggest that - learning from experience - optimism diminishes among entrepreneurs (Fraser and Green, 2006). In other words: Learning about the facts of business causes entrepreneurs to evaluate entrepreneurial opportunities more rigorously; the number of opportunities that are perceived (Shane, 2000) and considered viable at the same time, will thus decline with business and entrepreneurial experience, including the perceived opportunities for sustainable entrepreneurship. This is the case because opportunities for sustainable entrepreneurship are likely to be associated with a reduced level of organizational legitimacy. While such ventures certainly rank high in terms of moral legitimacy (Suchman, 1995), they are very likely to 
rank low in terms of pragmatic legitimacy (given their inherent innovativeness). This low level of pragmatic legitimacy makes the realization of opportunities for sustainable entrepreneurship potentially more challenging than the realization of more conventional opportunities. Moreover, several researchers (e.g., Starr and Macmillan, 1990; Aldrich and Fiol, 1994; Zimmerman and Zeitz, 2002; Delmar and Shane, 2004) have argued that a venture's legitimacy, as perceived by key stakeholders, would be an essential resource to overcome a venture's liabilities of newness (Stinchcombe, 1965), since pursuing a legitimate business model allows easier acquisition of other crucial resources (Dowling and Pfeffer, 1990). Given that opportunities for sustainable entrepreneurship are likely to bring in their wake radical changes of the dominant design within any given industry, we expect the link of sustainability orientation and entrepreneurial intentions to be weakened by business experience, as experienced business people will be more aware than the inexperienced of the challenges that accompany pursuing such opportunities. All in all, we interpret these findings as indicators of an increasing emphasis that individuals place on the viability of opportunities for sustainable entrepreneurship, that is to say, with increasing business experience, a form of 'reality check' takes place that leads to favoring harvesting entrepreneurial rents over other forms of benefits. We therefore propose:

$\mathrm{H} 2$ : The positive relationship between an individual's sustainability orientation and entrepreneurial intention will be stronger for individuals inexperienced in business matters than for experienced individuals.

\section{Method}

\subsection{Data}

This study is primarily based on a sample of students and alumni of science and engineering degree programs at the Technical University of Munich (TUM), one of Germany's largest and most reputable technical universities. We consider this sample to be particularly suitable to illustrate the hypothesized diminution effect of business experience on the relationship of sustainability orientation and entrepreneurial intention, given that engineering and science students are usually not trained in economics and are therefore not familiar with concepts such as profit maximization. Hence, a focus on pure rent seeking, which may be in conflict with sustainability-oriented aims is extremely unlikely among this population. On the other hand, alumni of these programs have had the chance to gain extensive business experience, for instance from positions in industrial engineering or from contact with people in pure business functions. Furthermore, we have additionally gathered data from business students at two other universities operating in a similar institutional setting as TUM.

Since June 2006 and prior to our main survey, pre-tests were carried out to ensure that the scales for the constructs used in our empirical analysis are valid and reliable. Whilst we largely use tested scales and constructs, we ensured through these pre-tests that these were also well understood and usable amongst our target population. For the first survey, we used a web-based online questionnaire and contacted students through the mailing lists of a large number of courses taking place in the 2007 summer semester 
and the $2007 / 2008$ winter semester. Whilst the total number of students participating in these courses is smaller than the target population of all students of science and engineering degree programs, this problem of reduced coverage is not critical since we also put information about the survey on the homepage of the TUM student portal. This portal is regularly accessed by all science and engineering students of TUM. To contact TUM alumni of science and engineering degree programs and to invite them to participate in the survey, we used the official alumni mailing list of TUM. For students, a first invitation to participate in the survey was send out mid-2007 followed by a reminder 10 days later. Subsequently, an invitation was sent to more students late in 2007, followed by a reminder at the end of 2007 and another one a month later at the beginning of 2008. The responses received as a result of all mailings yielded a response rate of $14.4 \%$ (corresponding to 357 student responses) which is acceptable for this type of survey. For the alumni, a first invitation was sent out in 2007 by e-mail. This was followed up with a reminder to an updated and extended list of alumni three weeks later. The responses received through these two mailings correspond to a response rate of $14.7 \%$ (equaling 162 responses from alumni) which is deemed satisfactory for this type of survey. ${ }^{2}$ Data from business students was collected during a joint French-German survey at Würzburg, another German university operating under the same institutional regime as TUM (which does not have a pure business administration undergraduate course and hence could not be involved), and Strasbourg, a French university located by Germany's boarder and relatively similar to German universities in terms of institutional regime. Furthermore, the cultural traditions, social norms and policies are very alike in both countries. For this second survey, a shortened versions of the original questionnaire was used in the same fashion and based on the same procedure as at TUM. Students at both universities were invited to participate in the survey during the time period of January to April 2009. The responses received as a result of all mailings yielded a response rate of $30.0 \%$.

Even though the response rates in all samples can be considered acceptable, selfassessment and self-exclusion of respondents may be a cause of distortions in the data set, in particular common method, common source and non-response bias. Common method bias results from variance in the data being more attributable to a measurement method than to the constructs measured (Podsakoff et al., 2003). Notably, the extent of common method bias varies between disciplines and is below average in the fields of marketing and business (Cote \& Buckley, 1987). In addition, self-assessment or soliciting data on independent or dependent variables does not in itself imply the existence of common method bias, since its strength can vary amongst sub-groups of respondents (e.g., respondents from different degree programs or student as against alumni respondents) and since method-related variance can deflate or inflate the relationships observed (Cote and Buckley, 1987; Podsakoff et al., 2003). For the survey data used here, a number of steps were taken (both procedurally and statistically) to ensure that common method bias is minimized. Procedurally, the study used different response formats, ensured the anonymity of respondents and that question order was counter-balanced and scale items were improved, especially throughout the pre-test

2 The sample sizes for the analysis to follow are slightly reduced since not all students and alumni responded to all questions. 
phase of the survey. All of these steps were aimed at reducing socially desirable responses and item ambiguity. For the sake of the anonymity of respondents, it was not possible to employ other procedural remedies, such as separating measurements. However, the design of the web-based survey allowed respondents to store a partially completed survey and to continue its completion at a later time, so that in principle, even this last remedy could be applied by respondents. In terms of statistical ex post evaluation of the presence of common method bias in the data finally used in the analysis, Harman's single-factor test (Harman, 1967; Podsakoff et al., 2003) was used to establish whether one single factor could be identified as accounting for most of the variance in the data from the unrotated solution of a factor analysis. The principle rationale behind this procedure is that if common method or source bias were an issue, then a factor analysis would yield a single factor or one clearly dominant factor accounting for the largest share of variance in the data. Since conducting this test did not result in a strong first factor, neither common method, nor common source bias seem to be a critical issue in the data in terms of both ex ante procedural precautions and ex post statistical evidence. We therefore consider it safe to continue with the analysis, even though the dependent and independent variables were collected at the same time with the same measurement instrument.

Regarding potential non-response bias, it could be possible that the replies received contain a disproportionate number of individuals that are particularly concerned about sustainability. Such a bias is a frequent problem of surveys based on written questionnaires (Armstrong \& Overton, 1977), and similar issues could be expected for web-based surveys. However, there is broad variability in the responses, indicating that the data also includes many individuals less concerned about sustainability. Further, the framing of the survey did not point to any particular relevance of the questions related to sustainability concerns. Since non-respondents are usually assumed to be more similar to late respondents than to early respondents, samples were - following recommendations set forth by Homburg and Bucerious (2006) - divided into thirds according to the time between initial contact and completion of the questionnaire. The comparison revealed no significant differences; hence, we did not find any indication of non-response bias in the data.

Insert Table 1 about here

Table 1 provides an overview of the descriptive statistics, correlations and variance inflation factors (VIF) of the data. Prior to our analysis, we ensured that our data conformed to the assumptions required for regression analysis. We checked the VIFs for evidence of multicollinearity; yet their numerical values were all well below the cut-off value of 10 suggested by Neter et al. (1996). This assures us that multicollinearity is not a problem with the data at hand. We also tested for heteroskedasticity, but found no evidence for this on the basis of the Breusch-Pagan / Cook-Weisberg test statistic $\left(\chi^{2}(1)=0.78, p=0.18\right)$. 


\subsection{Measures}

The main measures used in the survey are sets of items to measure traits such as sustainability orientation, personal attitudes towards entrepreneurial activities, and an individual's originality and innovativeness, as well as items reflecting contextual factors such as perception of barriers and support factors for entrepreneurial activities. Moreover, a number of demographic and control variables, such as age, gender, whether the respondent's parents are or have been self employed, and the specific degree course studied by the respondent were included.

Sustainability orientation was measured through items rated on a 5-point scale ranging from not at all accurate to very accurate. Given no established definition exists of such sustainability orientation, we had to derive our own items based on the literature reviewed from the fields of environmental psychology, environmental and social entrepreneurship and sustainability management. Based on a synthesis of these streams of literature we operationalized sustainability orientation by means of six items referring to environmental protection and social responsibility. We argue that these items essentially reflect underlying attitudes and convictions and provide a link between those and entrepreneurial intention focused on sustainable development to be expected by the individual expressing them to a high degree. Our items are "German firms should take an internationally leading role in the field of environmental protection"; "Firms that are environmentally oriented have advantages in recruiting and retaining qualified employees"; "The environmental performance of a company will in future be considered more and more by financial institutions"; "Corporate social responsibility should be part of the foundations of each company"; "I think that environmental problems are one of the biggest challenges for our society"; and "I think that entrepreneurs and companies need to take on a larger social responsibility". Given that Cronbach's $\alpha$ is over 0.64 for these six items, we calculate one index of sustainability orientation based on them. ${ }^{3}$

Attitude towards self-employment is featured prominently in the entrepreneurship literature as a determinant for entrepreneurial activity of individuals (e.g., Hisrich et al., 2007). We therefore include items to measure this construct by means of a 5-point scale ranging from strong agreement to strong disagreement. The items used to operationalize this attitude are "l'd rather be my own boss than have a secure job", "You can only make big money if you are self-employed" and "l'd rather found a new company than be the manager of an existing one". Cronbach's $\alpha$ of an index constructed of these items is 0.65 .

The entrepreneurship literature increasingly stresses the role of emotion as a factor operating alongside rational elements when opportunities are recognized, evaluated and exploited (e.g., Baron, 2004; 2008). Whilst sustainability orientation clearly has an emotional and inspirational component, it is necessary to control for the rational element in entrepreneurship as well to better separate specific mechanisms. We therefore measure and control for an individual's propensity to innovate addressing the cognitive

\footnotetext{
${ }^{3}$ An alpha value of 0.6 is deemed appropriate for sufficient reliability of exploratory or new constructs (Peterson 1994) as it is the case in this study.
} 
capabilities required to recognize entrepreneurial opportunities. To do so, we recur to the well-known Kirton-Adoption-Innovation (KAI) index (Kirton, 1976, 2003; Marcati et al., 2008; Bagozzi and Foxall, 1995). Various studies have confirmed the KAl inventory's relevance (cf. Taylor, 1989a, for applications in the human resources context and Bobic et al., 1999, for an application in the entrepreneurship context). Whilst a unidimensional version of the index has been proposed based on the original 32-item version of the KAl index, it is now generally accepted that its items load on three factors in the abridged 13-item version commonly used today (Foxall \& Hackett, 1992; Taylor, 1989b; Marcati et al., 2008). The first of these, termed originality, describes how comfortable a person is with new ideas, whereas the second and third (termed efficiency and conformity) refer to Weberian and Mertonian concepts of bureaucracy and meritocracy. The latter two concepts refer to important entrepreneurial dispositions such as team and consumer orientation (Foxall, 1994), ambiguity tolerance and need for achievement (Buttner and Gryskiewicz, 1993) and therefore provide controls to more narrowly identify the most relevant mechanism (e.g., sustainability orientation versus more rationally driven propensity to innovate). Each item of the KAl index is measured on a 5-point scale ranging from 1 (strong disagreement) to 5 (strong agreement). We confirm these three factors in our samples based on principal component analysis but given our focus on entrepreneurial intention, we use mainly the first factor of the KAI index in our empirical analysis to operationalize an individual's propensity to innovate (even though we involve the bureaucracy and meritocracy constructs in variants of our analysis). The Cronbach's $\alpha$-values for these three indices constructed on the basis of the KAl items are $0.77,0.74$ and 0.70 , respectively, which indicates sufficiently good reliability. ${ }^{4}$

A broader set of contextual factors has been proposed in the literature to influence the intention to become self-employed (Pennings and Kimberly, 1997; Naffziger et al., 1994; Chrisman et al., 2005). Franke and Lüthje (2003) carried out an exhaustive analysis of such factors in qualitative interviews as well as quantitative surveys of business students. Based on these they identified six items of particular salience and by means of confirmatory factor analysis establish that these can be divided into perceived support factors for and perceived barriers to becoming self employed. Hence, we make use of these items, as it is advocated in research methodology literature (Churchill and Peter, 1984) that researchers should make use as often as possible of existing measurement instruments, rather than developing their own, in order to enhance comparability of research results. The items reflecting perceived barriers are measured on a 5-point scale and are "Banks do not readily give credit to start up companies", "State laws (rules and regulations) are adverse to running a company" and "It is hard to find a business idea for a business that hasn't been realized before". The items used to

\footnotetext{
${ }^{4}$ The correlation between an index based only on the first factor of the KAI index and an innovation propensity index based on all 13 items of the three factors identified for the KAl index is 0.65 and highly significant. Hence it does not matter much statistically, which of the two versions is used in the operationalization. Opposed to this, the correlation between sustainability orientation and these two variants, which could be used to operationalize innovativeness based on the KAI index, is always insignificant. This confirms that sustainability orientation and innovativeness are (at least statistically) independent dimensions and that hence also analyzing their interaction could be appropriate (see footnote 9).
} 
operationalize perceived support factors (again on a 5-point scale) are "Entrepreneurs have a positive image within society", "Qualified consultancy and service support for new companies is available" and "The creative atmosphere at [my institution] inspires the development of ideas for new businesses". As before for the constructs of sustainability orientation, propensity to innovate and attitudes towards entrepreneurship, and given that the unidimensionality of these constructs has been established in extant research, we create indices for perceived barriers and support factors as well.

Insert Table 2 about here

Lastly, the dependent variable entrepreneurial intention is a self-evaluation by the respondents of the extent to which they agree with the statement that they will be selfemployed within the next five years. ${ }^{5}$ Table 2 summarizes the distribution of responses for our dependent variable and provides a breakdown by sub-sample. ${ }^{6}$ In defining our dependent variable, we did not focus on intentions to pursue sustainable entrepreneurship because the literature (e.g., Dean and McMullen 2007) suggests that which opportunities contribute most to sustainability is not always intuitive. For example, impacts along the supply chain or rebound effects are indirect or long-term effects and often cannot be easily assessed. Therefore we concur with Spence et al. (2007) that if individuals have a high sustainability orientation and plan to become self-employed, they will usually incorporate sustainability considerations when conceptualizing their ventures. Assuming the opposite would lead to the paradox situation in which acting entrepreneurially would not counter initial dissatisfaction but would rather increase it. Furthermore, based on in depth case-studies Schlange (2006) shows that prior sustainability-related motivations and emotions cause subsequent entrepreneurial acts which justifies framing entrepreneurial intentions as the dependent variable.

\subsection{Modeling}

With regard to econometric modeling, given that the dependent variable of the analysis is ordinal, linear multiple regression using ordinary least squares would be

\footnotetext{
5 The responses to this question are correlated with a question asking in the survey whether or not respondents are currently self-employed $(r=0.32, p<0.01)$, yet not to a level that they are multi-collinear. Hence including both variables in the analysis could provide additional insight but theoretical arguments advise against this (see also our explanations at the end of the modeling section of this paper).

${ }^{6}$ Whilst all the alumni in our first survey came from science and engineering backgrounds, a minority of them had subsequently acquired an MBA. Given the insights from the literature review and the arguments developed in our theory section, it could be that this minority differs significantly from the other alumni since they have acquired even more business related knowledge and thus business experience. However, comparing the mean scores of the latter alumni with those without MBA and that of the students reveals (based on an analysis of variance) that no significant differences exist between these groups in the propensity to become self-employed $(\mathrm{F}=2.18, \mathrm{p}=0.11)$ as well as their sustainability orientation $(F=2.07, p=0.13)$. Moreover, estimating the model reported in Table 3 for only those alumni who did not obtain an MBA does not change the results qualitatively.
} 
inappropriate, since the method may lead to biased and inefficient estimates of the coefficients of the explanatory variables in the case of binary or ordinal dependent variables (Long 2002). Hence, we use an ordinal probit model (Greene 2003) with the dependent variable being measured on a 5-point scale. The independent variables in the model are dummies for the degree course studied, and respectively for whether the respondents moved abroad for a practical placement or for their studies. Moreover, dummies for whether respondents finished a vocational training program prior to their studies, for gender, for age of the respondent, and for whether the respondents' parents are or have been self-employed were included. Finally, we added an index score for sustainability orientation, an index score for propensity to innovative based on the originality component of the KAl index, along with index scores for attitudes towards entrepreneurship, perceptions of difference and support factors as well.

Alongside the models reported in the results section, we also calculated models including risk taking propensity and locus of control and additional models using a binary dependent variable measuring whether respondents are currently self-employed or not. These modifications did not qualitatively alter our results nor did the latter change with the alternative dependent variable for which we also estimated instrumental variable models instrumenting attitude with additional variables such as locus of control and risk-taking propensity. Given that none of these modifications change our findings, we only report results for the estimations excluding risk-taking propensity and locus of control for reasons of model parsimony. This is consistent with Lüthje and Franke (2003), who argue that both locus of control and risk taking propensity are actually antecedents to attitudes towards entrepreneurial behavior, but not attitudes themselves ${ }^{7}$, and thus cannot be directly related to our dependent variable. Moreover, the entrepreneurship literature is consistently arguing that behavior follows intentions (Krueger et al., 2000), hence using an extra binary variable for behavior as described does not provide much additional insight and we therefore refrain from reporting results for this variable. Still we note that our results for this binary variable are consistent with our ordinal entrepreneurial intention variable used in the models reported in the following paragraphs, hence further corroborating and supporting our findings.

\section{Results}

The results ${ }^{8}$ of the model estimation are summarized in Table 3 . Notably, in all models (students as well as alumni) the dummies for the degree course studied were jointly significant; hence strongly justifying their initial inclusion, since their joint significance indicates that the propensity to become self-employed differs considerably across degree courses. As the $\mathrm{R}^{2}$ values show, the models for both, students as well as alumni have good overall fit. In addition to this, all models are significant overall, as is clarified by the respective $\chi^{2}$ statistics.

\footnotetext{
7 Especially where it addresses risk-taking propensity, the literature is also ambiguous in that some research suggests that entrepreneurs are moderate risk takers (Picot et al., 1989; Hisrich et al. 2007) which may imply a more neutral link between risk taking and entrepreneurship, thus further justifying our approach.

${ }^{8}$ For reasons of clarity and brevity marginal effects are not reported but are available from the authors.
} 
Insert Table 3 about here

With respect to the control variables, it can be seen in Table 3 that alumnae believe they are more likely to become self-employed in the future, while female business students do not consider entrepreneurial action as a viable career option. On the other hand, both student samples with self-employed parents are more likely to consider becoming self-employed. Moreover, attitudes towards entrepreneurship are for all samples significantly associated with a higher likelihood of intending to behave entrepreneurially. Both, students and alumni with a positive attitude towards entrepreneurship are thus more likely to intend to become self-employed. The same holds true for engineering students and alumni with a higher propensity to innovate, as measured by the KAI index originality component. The effect of traits and contextual factors is furthermore largely supported by our data.

With respect to $\mathrm{H} 1$ and $\mathrm{H} 2$, we find that engineering students with a stronger sustainability orientation are indeed more likely to intend to become self-employed. However, this effect completely vanishes when inspecting the business student and the alumni sample. ${ }^{9} \mathrm{H} 1$ is thus only partially supported; sustainability orientation does indeed influence entrepreneurial intention, but not for every group of individuals. This is due to the fact that the effects reflected by $\mathrm{H} 2$ turned out to be even stronger than hypothesized: Not only is the effect of sustainability orientation for the business student and the experienced alumni sample lower than for the inexperienced engineering student sample, but it is virtually non-existent. The Chow test confirms that the difference of the sustainability orientation coefficients in the regression models estimated for the two groups of engineering students and alumni is also significant $(p=$ 0.056). Whilst the difference of these two groups and the group of business students is not significant, the coefficients relative to one another are fully consistent with the reasoning underlying our hypotheses. Since business students are a group that is characterized by a higher exposure to business education than engineering students, but a lower exposure to business experience than the alumni group, the coefficient is expected to take a value between those of the two other groups. This is precisely what we find and thus, $\mathrm{H} 2$ is also supported by our data. ${ }^{10}$ Furthermore, investigating the

\footnotetext{
9 This result remains qualitatively stable if we use a standard normal transformation of our initial sustainability measure (based on the mean and standard deviation for the student and alumni samples, respectively) as an alternative and relative measure of sustainability orientation. Results for this variable are available upon request. The results also do not change in terms of coefficient size, sign and significance when we include the bureaucracy and meritocracy constructs of the KAl inventory to proxy for aspects of individual dissatisfaction in the estimation model.

10 In a variation of our model we also included a centered interaction term of sustainability concern and propensity to innovate (i.e., the index score for the items of the KAl originality factor) in order to analyze the effects of very innovative sustainability-related entrepreneurial opportunities. We do not find significant positive associations for this interaction term and hence no evidence indicating that the stronger an individuals propensity to innovative the stronger the impact of sustainability orientation on entrepreneurial intention. We therefore conclude that inclusion of an interaction term does not give
} 
alumni sample only and introducing the alumni's work experience as a moderator of the relationship of sustainability orientation and entrepreneurial intentions results in a positive, significant interaction term, thus lending further support to $\mathrm{H} 2 .{ }^{11}$

\section{Discussion}

\subsection{The link between sustainability orientation and entrepreneurial intentions}

We proposed a goal of this paper to be to link the emergent literature of entrepreneurship for sustainable development to the larger body of literature determining the factors affecting entrepreneurial behavior and intentions. Thus we sought to integrate knowledge of conventional entrepreneurship with knowledge of sustainability issues. Moreover, by using large-scale survey data, the goal was to enhance the primarily conceptual literature on sustainable entrepreneurship with initial empirical insights. Our theoretical reasoning and our empirical results indicate that individual sustainability orientation can indeed explain entrepreneurial intention to some degree. The results are thus informative for researchers interested in the antecedents of entrepreneurial intention and can also be utilized to further establish sustainable entrepreneurship as an important sub-field of the entrepreneurship domain.

Our results are both encouraging and perturbing at the same time. While we find a substantial potential for exploiting sustainable development-oriented entrepreneurial opportunities among students, this obvious potential vanishes as business experience is gained. The literature review and the empirical results with respect to our second hypothesis suggest that, especially for less experienced students, concern with ethical, social and environmental issues is more likely to translate into entrepreneurial intention and subsequent potential entrepreneurial behavior. Thus, given that most entrepreneurial activity occurs with some time lag, that is, some years after completing a university program (Institute for Small Business Affairs Consortium, 2004; Chlosta et al., 2006), there is a gap between what students as potential future entrepreneurs believe they could do, and what they will actually do later on in their career. While we have argued in the theoretical section of this paper that the reason for this detrimental effect of business experience can be found primarily within the individual itself, alternative explanations could refer to external factors. For instance, recent research (Friedman and Tribunella, 2009) has shown that the market value of MBAs declines, if their school places an emphasis on awareness of corporate social and environmental responsibility. Thus, if entrepreneurial behavior is desirable (and especially sustainable entrepreneurial behavior), the challenge for the entrepreneurship community is clear:

insights beyond the results reported in Table 3. Furthermore, we also test for a mediating effect of the propensity to innovate on the link between sustainability orientation and entrepreneurial intention but have to reject this possibility as well, since the necessary conditions for a mediating effect (Baron and Kenny, 1986) are not fulfilled. Even when relaxing these conditions, as is sometimes done in the literature, at most a partial mediation effect for the student sample could be envisaged, yet the coefficients for sustainability orientation differ only marginally between the unmediated and mediated models ( 0.275 and 0.269 , respectively) and hence we consider this insufficient evidence for a mediating effect.

${ }^{11}$ Again, for reasons of brevity this model is not reported but available upon request from the authors. 
What measures can we take so as not to waste the obvious potential among our students?

Against this background and the findings from our empirical study, it is consequently not enough just to make students understand the role of ethics and social responsibility in actual management decisions (Kraft and Singhapakdi, 1991). The level of average sustainability orientation is already quite high in all of our samples (3.36 on a five-point scale). Therefore, highlighting in class the general sustainability challenges (such as climate change, water resource degradation or depletion of non-renewable resources such as oil) as well as the potential opportunities for sustainable entrepreneurship that result from these challenges should only be a first step. Still, students will benefit from learning that there can be more to entrepreneurship than just harvesting entrepreneurial rents. Entrepreneurship is able to provide benefits for sustainable development that can help maximize the entrepreneur's utility function (which is likely to be the case, if the non-monetary benefits, such as existence and option values from, for instance, preserving environmental public goods enter this function).

A key answer to the question of how the exploitation of opportunities for sustainable entrepreneurship can be encouraged seems to be - given the considerable complexity inherent to such opportunities - through entrepreneurial education. In free market economies, problems should be solved by following the subsidiarity principle. Since governments cannot easily decide which market imperfections leading to unsustainable solutions should be addressed by legislative means and which by private initiative, they should provide incentives that foster sustainable development-oriented entrepreneurial behavior, and then let the entrepreneurs decide which opportunities to pursue. In addition to incentivizing such sustainability entrepreneurs with, for example, tax incentives, sponsorship of awards and the like, we would urge policy makers to make every effort not only to support entrepreneurship resulting in technological innovation, but also entrepreneurship resulting in sustainable market offerings.

Entrepreneurial education can contribute to this goal and educators should focus both on the undergraduate and undergraduate level. ${ }^{12}$ Focusing on the undergraduate level enables early-on inclusion of sustainability issues, which potentially balances the effect of business exposure and may simultaneously help to realize a more positive moderating effect of the latter. However, given that we argue that the effect of sustainability orientation is affected by two different mechanisms relating to business exposure, namely conventional business education (stressing the profit maximization motive rather than the triple bottom line) and business experience (when entering the profession after the studies), it seems that graduate education also has an important effect and role to play. At this level, the effect of initial business experience could be powerfully moderated by educational intervention in a manner supporting individuals to still act entrepreneurial upon their sustainability orientation. However, at the alumni stage it may be a challenge to disentangle the two mechanisms because of an

12 An informal poll of 16 participants at a 2009 Academy of Management Conference session on sustainable entrepreneurship supports this notion in that $67 \%$ of the respondents present at this session felt that intervention should take place at both, the undergraduate and graduate level. 
additional educational effect through more informal corporate trainings. Therefore, graduate level educational intervention has to embrace an inclusive approach that not only offers master level degrees and modules, but also relates to executive and continuing education, especially when linked to corporate education.

To foster sustainable entrepreneurship, we therefore suggest that educators take the following measures as a minimum (ordered by priority). First and foremost, special attention should be paid to master's degree, executive and continuing education programs in order to close the gap apparently created by business experience. Individuals with considerable business experience are particularly qualified to implement business models based on opportunities for sustainable entrepreneurship (Politis, 2005). Given that one of the largest benefits of entrepreneurial education (besides the acquisition of knowledge about certain management instruments) is entrepreneurial inspiration (Souitaris et al., 2007), we consider the inclusion of more cases of successful sustainable entrepreneurship in courses targeted at experienced individuals to be essential. Moreover, providing a platform in class for entrepreneurs committed to pursuing sustainable business models will also enhance the level of entrepreneurial intention amongst their audiences. Second, the potential of market imperfections to reveal sustainable entrepreneurial opportunities should be a standard component of every entrepreneurship curriculum. At the same time, we deem it essential that not only the business student faction, but a wider congregation of people concerned about sustainability is awakened to the additional potential brought by sustainable entrepreneurship. Such individuals show a high propensity to act (Bruyere and Rappe, 2007 ) to achieve the goals of sustainability (for instance, grass-roots-activists affiliated to particular NGOs), but might not yet have considered economic action that would be in line with their sustainability orientation.

Entrepreneurship for sustainable development brought about in this way could complement high-tech entrepreneurship, which itself has been identified as an important factor of economic stability and prosperity (Daneke, 1989). This especially matters in the context of national systems of innovation: whether or not sustainability entrepreneurship is desirable in an economy is not independent of the orientation of its overall industrial policy. In Germany for example, it is the explicit goal of the government to strengthen the green technology sector in order to develop a national advantage and to increase international competitiveness in this field. However, managing entrepreneurial ventures to the triple bottom line admittedly comes with a double challenge: the venture has to be successful in economic terms as well as in terms of its sustainability.

\subsection{Limitations and Potential for Future Research}

Our results should be interpreted in light of some limitations that naturally emerge from the design of the study. First, analyzing a sample consisting mainly of students could be considered problematic to some extent. However, even though the subjects of the investigation are not actually engaged in sustainable entrepreneurial activities, future (sustainability) entrepreneurs are likely to be drawn from this particular population. We therefore feel that students (and alumni) are an extremely important group to study, 
since possession of a university degree has been shown to positively associate with entrepreneurial activity and intentions (Hisrich et al. 2007) and since graduates make up a large proportion of all entrepreneurially active individuals. Second, we believe that including environmental factors or different educational stimuli in the research design would be an interesting avenue for future research. This would permit the investigation of potentially moderating effects on the relationship in question. Furthermore, stronger linking of anecdotal evidence and large-scale survey data would contribute to an even better understanding. Another interesting approach would be to research operationalizations of entrepreneurial intention which would provide a route to distinguish conventional entrepreneurial intention from sustainable entrepreneurial intention. In this context nested multi-level designs seem to be particularly suited. ${ }^{13}$

Last, another aspect that potentially could confound the analysis is the nature of the reported link between sustainability orientation and entrepreneurial intentions. If over time, societal expectations that business ventures take sustainability into account increase, or if (relative to other opportunities) more sustainability-related opportunities become available, or if both trends occur at the same time, any association between sustainability orientation and entrepreneurial intention could become spurious. The impact of sustainability orientation on entrepreneurial intentions could thus not be attributed to individuals with higher sustainability orientation being more entrepreneurial, but would be driven by changes in societal expectations and the structure of the opportunity space. Given that changes in expectations and opportunity sets take place over time, this could only be addressed through separate controls with panel data. Not having such data to hand is clearly a limitation of our study that should be addressed in future by longitudinal research designs. Yet, our data has some quasi-longitudinal element, in that we survey three broadly defined cohorts, which are at different stages of their professional lifecycle, student or graduate. Assuming that changes in social expectations and greater sustainability-related opportunities (or both jointly) would be the only reason for an association between sustainability orientation and entrepreneurial intention, this should not lead to the observed differences between students and alumni, since changes in expectations or opportunity sets at one point in time should similarly affect all entrepreneurially-minded individuals. In this case, the sustainability orientation of alumni should be significantly associated with entrepreneurial intention, if increased sustainability-related opportunities or increased societal expectations are indeed the only factors that matter. Empirically however, we find that this is not the case, and therefore we can indirectly infer that factors other than societal expectations or qualitative changes in the opportunity space - and specifically an individual's sustainability orientation - do matter.

Another aspect to be considered here is whether in recent years the share of sustainability-related opportunities, relative to the totality of all opportunities did in fact increase. First, whilst it is clear that environmental impacts have materialized strongly in the public's awareness in recent years, other types of entrepreneurial opportunities increased significantly too. Telling examples are the first dot-com boom up until the year

\footnotetext{
${ }^{13}$ We are grateful to one anonymous reviewer for pointing this potential improvement in future research designs out to us.
} 
2000 and the recent upsurge of Web 2.0 start-ups (Britton and McGonegal, 2007). This fact should simply caution against the assumption that observing an increase in sustainability-related opportunities per se permits the conclusion that they are necessarily highly likely to be pursued by entrepreneurs. Second, societal expectations have in recent years certainly become much more demanding. However, these demands are quite often addressed towards established firms which have a significant impact because of the considerable size of their operations. Therefore, increasing societal demands per se also do not imply that entrepreneurs would more often pursue sustainability-related opportunities. Startups are just as likely to pursue conventional opportunities and compensate for their potentially negative social or environmental impact with the usual corporate social responsibility activities. There is evidence that most entrepreneurial ventures behave in exactly this way (Graafland et al., 2003; Jenkins, 2006; Williamson et al., 2006) and hence it could well be that the share of sustainability-related opportunities does not increase just because societal expectations change. In fact, as outlined in the theoretical section, an important precondition for the share of sustainability-related opportunities increasing in the light of changed societal expectations should be that an entrepreneur's utility function is affected by nonmonetary benefits, existence or option values so that pure profit maximization cannot guarantee that entrepreneurs maximize their utility function. Individuals with stronger sustainability orientations are precisely those that value non-monetary benefits, as well as existence and option values with regard to environmental goods. Therefore, the link we propose in $\mathrm{H} 1$ would be a necessary condition for an increase of the share of sustainability-related opportunities relative to all opportunities pursued, even in the light of increasing societal demands. In this context, the actual process of pursuing a sustainability-related opportunity in terms of being allocation- or discovery-driven as embodied in the concepts of causation and effectuation (Sarasvathy, 2001; Sarasvathy et al. 2003) seems to be of particular relevance for future research. Pursuing this link would also help to further refine our findings and the reasoning behind it.

\section{Conclusion}

With this study we aimed to contribute to the growing empirical literature on sustainable entrepreneurship by synthesizing results from the literature of entrepreneurial intentions, sustainable entrepreneurship, and entrepreneurship education. In this respect we were able to provide evidence that knowing the sustainability orientation of individuals can indeed add to our understanding of entrepreneurial intentions; moreover, we were able to highlight an important aspect of this relationship, namely its declining impact under the influence of business experience.

\section{Acknowledgements}

We would like to thank the editors Michael Lenox, Gregory A. Daneke and Jeremy Hall as well as the two anonymous reviewers of the Journal of Business Venturing for their comments and guidance. Also, seminar and workshop participants at Cass Business School (London), the ICSB World Conference 2009 (Seoul) and the Academy of Management Annual Meeting 2009 (Chicago) provided valuable feedback and insights. 


\section{References}

Ajzen, I., 1991. The theory of planned behavior. Organisational Behavior and Human Decision Processes 50 (2), 1-63.

Ajzen, I., Fishbein, M., 1977. Attitude-behavior relations: A theoretical analysis and review of empirical research. Psychological Bulletin 84, 888-918.

Aldrich, H.E., Fiol, C.M., 1994. Fools rush in? The institutional context of industry creation. Academy of Management Review 19 (4), 645-670.

Anderson, T.L., Leal, D.R., 1997. Enviro-capitalists. Doing good while doing well. Rowman \& Littlefield, Lanham, MD.

Arabsheibani, G., de Meza, D., Maloney, J., Pearson, B., 2000. And a vision appeared unto them of a great profit: evidence of self-deception among the self-employed. Economic Letters 67, 35-41.

Aragon-Correa, J.A., Sharma, S., 2003. A contingent resource-based view of proactive corporate environmental strategy. Academy of Management Review 28 (1), $71-$ 88.

Armstrong, J.S., Overton, T.S., 1977. Estimating nonresponse bias in mail surveys. Journal of Marketing Research 14, 396-402.

Bagozzi, R.P., Foxall, G.R., 1995. Construct validity and generalizability of the Kirton Adaption-Innovation Inventory. European Journal of Personality 9, 185-206.

Baum, J.R., Frese, M., Baron, R.A., Katz, J.A., 2007. Entrepreneurship as an area of psychological study: An introduction. In: Baum, J.R., Frese, M., Baron, R.A. (Eds.), The psychology of entrepreneurship. Lawrence Earlbaum, Mahwah, NJ, pp. 1-18.

Baron, R. A., 2004. The cognitive perspective: A valuable tool for answering entrepreneurship's basic "why" questions. Journal of Business Venturing 19 (2), 221-239.

Baron, R. A., 2008. The role of affect in the entrepreneurial process. Academy of Management Review 33 (2), 328-340.

Baron, R.M., Kenny, D. A., 1986. The Moderator-Mediator Variable Distinction in Social Psychological Research: Conceptual, Strategic, and Statistical Considerations. Journal of Personality and Social Psychology 51 (6), 1173-1182.

Bennett, S.J., 1991. The complete guide to small business opportunities from the environmental revolution. Wiley, New York, NY. 
Benton, R., 1989. Environmental knowledge and attitudes of undergraduate business students compared to non-business students. Business \& Society 33, 191-211.

Berle, G., 1991. The green entrepreneur: business opportunities that can save the earth and make you money. Liberty Hall Press, Blue Ridge Summit, PA.

Bhave, M.P., 1997. A process model of entrepreneurial venture creation. Journal of Business Venturing 9 (3), 223- 242.

BMU, ed., 1998. Umweltbewusstsein in Deutschland 1998. Ergebnisse einer repräsentativen Bevölkerungsumfrage. Bundesministerium für Umwelt, Naturschutz und Reaktorsicherheit, Berlin.

BMU, ed., 2000. Umweltbewusstsein in Deutschland 2000. Ergebnisse einer repräsentativen Bevölkerungsumfrage. Bundesministerium für Umwelt, Naturschutz und Reaktorsicherheit, Berlin.

BMU, ed., 2002. Umweltbewusstsein in Deutschland 2002. Ergebnisse einer repräsentativen Bevölkerungsumfrage. Bundesministerium für Umwelt, Naturschutz und Reaktorsicherheit, Berlin.

Britton, D.B., McGonegal, S., 2007. The Digital Economy Fact Book. The Progress \& Freedom Foundation, Washington, DC.

Bobic, M., Davis, E., Cunningham, R., 1999. The Kirton adaptation-innovation inventory: Validity issues, practical questions. Review of Public Personnel Administration 19, 18-31.

Borzaga, C., Solari, L., 2001. Management challenges for social enterprises, In: Borzaga, C., Defourny, J., (Eds.), The Emergence of Social Enterprises. Routledge, New York ,NY, pp. 333-49.

Brazeal, D.V., Herbert, T.T., 1999. The genesis of entrepreneurship. Entrepreneurship Theory and Practice 23 (3), 29-45.

Bright, D.S., Fry, R., Cooperrider, D.L., 2006. Transformative innovations for mutual benefit in business, society and environment. Paper presented at the Academy of Management Meeting 2006, Atlanta, 11-16 August 2006.

Brinckerhoff, P.C., 2000. Social entrepreneurship: The art of mission-based venture development. John Wiley \& Sons, New York, NY.

Bruyere, B., Rappe, S., 2007. Identifying the motivations of environmental volunteers. Journal of Environmental Planning and Management 50 (4), 503-516.

Buttner, E.H., Gryskiewicz, N., 1993. Entrepreneurs' problem-solving styles: An empirical study using the Kirton adaption/innovation theory. Journal of Small Business Management 31 (1), 22-31. 
Chlosta, S., Klandt, H., Johann, T., 2006. German Survey on Collegiate Entrepreneurship. Working Paper, European Business School, Oestrich-Winkel.

Chrisman, J., McMullan, E., Hall, J., 2005. The influence of guided preparation on the long-term performance of new ventures. Journal of Business Venturing 20 (6), 769-791.

Churchill, G.A., Peter, J.P., 1983. Research design effects on the reliability of rating scales: A meta-analysis. Journal of Marketing Research 21 (4), 360-375

Coase, R.H., 1974. The lighthouse in economics. Journal of Law and Economics 17 (2), 357-376.

Cohen, B., 2006. Sustainable valley entrepreneurial ecosystems. Business Strategy and the Environment 15, 1-14.

Cohen, B., Smith, B., Mitchell, R., 2008. Toward a sustainable conceptualization of dependent variables in entrepreneurship research. Business Strategy and the Environment 17, 107-119.

Cohen, B., Winn, M.I., 2007. Market imperfections, opportunity and sustainable entrepreneurship. Journal of Business Venturing 22, 29-49.

Cote, J.A., Buckley, M.R., 1987. Estimating trait, method and error variance: Generalizing across 70 construct validation studies. Journal of Marketing Research 24, 315-318.

Daneke, G.A., 1989. Technological entrepreneurship as a focal point of economic development policy: A conceptual re-assessment. Policy Studies Journal 17 (3), 643-655.

Dean, T.J., McMullen, J.S., 2007. Toward a theory of sustainable entrepreneurship: Reducing environmental degradation through entrepreneurial action. Journal of Business Venturing 22, 50-76.

Delmar, F., Shane, S., 2004. Legitimating first: Organizing activities and the survival of new ventures. Journal of Business Venturing 19 (3), 385-410.

Dembkowski, S., Hamner-Lloyd, S., 1994. The Environmental Value-Attitude-System model: A Framework to Guide the Understanding of Environmentally-conscious Consumer Behaviour. Journal of Marketing Management 10, 593-603.

Desa, G., Kotha, S., 2006. Ownership mission and environment: an exploratory analysis into the evolution of a technology social venture. In: Mair, J., Robertson, J., Hockerts, K. (Eds.), Social Entrepreneurship. Palgrave Macmillan, New York, NY, pp. 155-79. 
Diekmann, A., Preisendörfer, P., 1991. Umweltbewusstsein, ökonomische Anreize und Umweltverhalten. Schweizerische Zeitschrift für Soziologie 17, 207-231.

DiMaggio, P., 1988. Interest and Agency in Institutional Theory. In: Zucker, L.G. (Ed.), Institutional Patterns and Organizations. Culture and Environment. Ballinger, Cambridge MA, pp. 3-21.

Dowling, J., Pfeffer, J., 1975. Organizational legitimacy: Social values and organizational behaviour. Pacific Sociological Review 18 (1), 122-136.

Elkington, J., 1997. Cannibals with forks: The triple bottom line of 21 st century business. New Society Publishers, Gabriola Island, Canada.

Foxall, G.R., Hackett, P.M.W., 1992. The factor structure and construct validity of the Kirton adaption-innovation inventory. Personality and Individual Differences 13 (9), 967-975.

Fraser, S., Greene, F.J., 2006. The effects of experience on entrepreneurial optimism and uncertainty. Economica 73, 169-192.

Friedman, B.A., Tribunella, T., 2009. Does the MBA Employment Market Value Awareness of Social and Environmental Responsibility? Paper presented at the Academy of Management Meeting 2009, Chicago, 7-11 August 2009.

Gartner, W.B, 1988. "Who is an entrepreneur?" is the wrong question. American Journal of Small Business 12, 11-32.

Graafland, J., van de Ven, B., Stoffele, N., 2003. Strategies and Instruments for Organising CSR by Small and Large Businesses in the Netherlands. Journal of Business Ethics 47 (1), 45-60.

Greene, W.H., 2003. Econometric analysis. Prentice-Hall, Upper Saddle River, NY.

Hall, J., Vredenburg, H., 2003. The challenges of sustainable development innovation. MIT Sloan Management Review 45 (1), 61-68.

Hardin, G., 1968. The tragedy of the commons. Science 162, 1243-1248.

Harman, H.H., 1967. Modern factor analysis. University of Chicago Press, Chicago, IL.

Hanley, N., Spash, C., 1992). Cost Benefit Analysis and the Environment. Edward Elgar, Aldershot.

Hisrich, R.D., Peters, M.P., Shepherd, D.A., 2007. Entrepreneurship (7th ed.). McGrawHill, New York, NY. 
Homburg, C., Bucerius, M., 2006. Is speed of integration really a success factor of mergers and acquisitions? An analysis of the role of internal and external relatedness. Strategic Management Journal 27 (4), 347 - 368.

Institute for Small Business Affairs Consortium, 2004. Making the journey from student to entrepreneur: A review of the existing research into graduate entrepreneurship. Research paper, National Council for Graduate Entrepreneurship, Birmingham.

Isaak, R., 1999. Green Logic: Ecopreneurship, theory and ethics. Kumarian, West Hartford, CT.

Jaffe, A.B., Stavins, R.N., 1994. Energy-efficiency investments and public policy. The Energy Journal 15 (2), 1-23.

Jenkins, H., 2006. Small Business Champions for Corporate Social Responsibility. Journal of Business Ethics 67 (3), 241-256.

Keh, H.T., Foo, M.D., Lim, B.C., 2002. Opportunity evaluation under risky conditions: The cognitive processes of entrepreneurs. Entrepreneurship Theory and Practice 27, 125-148.

Keogh, P.D., Polonsky, M.J., 1998. Environmental commitment: A basis for environmental entrepreneurship? Journal of Organizational Change Management 11 (1), 38-49.

Kirton, M.J., 1976. Adaptors and innovators: A description and measure. Journal of Applied Psychology 61 (5), 622-629.

Kirton, M.J., 2003. Adaption-innovation: in the context of diversity and change. Routledge, London, UK.

Kirzner, I.M., 1985. Discovery and the capitalist process. University of Chicago Press, Chicago, IL.

Kraft, K.L., Singhapakdi, A., 1991. The role of ethics and social responsibility in achieving organizational effectiveness: Students versus managers. Journal of Business Ethics 10, 679-686.

Krueger, N.F., Reilly, M.D., Carsrud, A.L., 2000. Competing models of entrepreneurial intentions. Journal of Business Venturing 15, 411-432.

Kyrö, P., 2001. To grow or not to grow? Entrepreneurship and sustainable development. International Journal of Sustainable Development and World Ecology 8 (1), 1528.

Larson, A.L., 2000. Sustainable innovation through an entrepreneurship lens. Business Strategy and the Environment 9, 304-317. 
Lee, A.S., Baskerville, R.L., 2003. Generalizing Generalizability in Information Systems Research. Information Systems Research 14 (3), 221-243.

Lehmann, M., Christensen, P., Møller Larsen, J., 2005. Self-regulation and new institutions. The case of green networks in Denmark. In Sharma, S., AragónCorrea, J.A. (Eds.), Corporate Environmental Strategy and Competitive Advantage. Edward Elgar, Northampton, MA, pp. 286-308.

Lenox, M. 2006., The role of private, decentralized institutions in sustaining industry self-regulation. Organization Science 17 (6), 670-690.

Linnanen, L., 2002. An insider's experience with environmental entrepreneurship. Greener Management International 38, 71-80.

Long, J.S., 2002. Regression models for categorical and limited dependent variables. Sage, Thousand Oaks, CA.

Lüthje, C., Franke, N., 2003. The 'making' of an entrepreneur: testing a model of entrepreneurial intent among engineering students at MIT. R\&D Management 33 (2), 135-147.

Mair, J., Robinson, J. Hockerts, K., 2005. Social entrepreneurship. Palgrave Macmillan, New York, NY.

Marcati, A., Guido, G., Peluso, A.M., 2008. The role of SME entrepreneurs' innovativeness and personality in the adoption of innovations. Research Policy 37 (9), 1579-1590.

Milstein, M.B., London, T., Hart, S., 2006. Capturing the opportunity of creating a more inclusive capitalism. Paper presented at the Academy of Management Meeting 2006, Atlanta, 11-16 August 2006.

Mitchell, R.K., Busenitz, L., Lant, T., McDougall, P.P., Morse, E.A., Smith, J., 2002. Toward a theory of entrepreneurial cognition: Rethinking the people side of entrepreneurship research. Entrepreneurship Theory and Practice 27, 93-104.

Naffziger, D.W. Hornsby, J.S., Kuratko, D.F., 1994. A proposed research model of entrepreneurial motivation. Entrepreneurship Theory and Practice, 18 (3), 29-42.

Neter, J., Kutner, M.H., Wasserman, W., Nachtsheim, C.J., 1996. Applied linear statistical models (4th ed.). McGraw-Hill, New York, NY.

Nicolls, A., 2006. Social entrepreneurship - new models of sustainable social change. Oxford University Press, Oxford, UK.

Oppenheimer, M., 2006. Science and Environmental Policy: The Role of Nongovernmental Organizations. Social Research 73 (3), 881-890. 
Parsa, F., Lankford, W.M., 1999. Student's views of business ethics: An analysis. Journal of Applied Psychology 29 (5), 1045-1057.

Pastakia, A., 1998. Grassroots ecopreneurs: Change agents for a sustainable society. Journal of Organizational Change Management 11 (2), 157-173.

Pennings, J., Kimberly, J., 1997. Environmental influences on the creation process. In: Miles, R. (Ed.), The Organizational Life Cycle. Issues in the creation, transformation, and decline of organizations. Jossey-Bass, San Francisco, CA, pp. 135-160.

Peterson, R.A., 1994. A meta-analysis of cronbach's coefficient alpha. Journal of Consumer Research 21 (2), 381-391.

Pfeiffer, F., Reize, F., 2000. Business Start-ups by the Unemployed - an Econometric Analysis based on Firm Data. Labour Economics 7 (5), 629-663.

Picot, A., Schneider, D., Laub, U., 1989. Transaktionskosten und innovative Unternehmensgründungen. Zeitschrift für betriebswirtschaftliche Forschung 26, $358-387$.

Podsakoff, P.M., MacKenzie, S.B., Lee, J.Y., Podsakoff, N.P., 2003. Common method biases in behavioral research: A critical review of the literature and recommended remedies. Journal of Applied Psychology 88 (5), 879-903.

Politis, D., 2005. The Process of Entrepreneurial Learning: A Conceptual Framework. Entrepreneurship Theory and Practice 29 (4), 399-424.

Prahalad C.K., Hammond A., 2002. Serving the world's poor, profitably. Harvard Business Review 80 (9), 48-57.

Prahalad, C.K., 2005. The fortune at the bottom of the pyramid: Eradicating poverty through profits. The Wharton School, Philadelphia, PA.

Prahalad, C.K., 2006. The innovation sandbox. Strategy and Business 44, 1-10.

Rauch, A., Frese, M., 2007. Let's put the person back into entrepreneurship research: A meta-analysis on the relationship between business owner's personality traits, business creation, and success. European Journal of Work and Organizational Psychology 16, 353-385.

Robinson, P.B., Stimpson, D.V., Huefner, J.C., Hunt, H.K., 1991. An attitude approach to the prediction of entrepreneurship. Entrepreneurship Theory and Practice 15, 13-31.

Sanstad, A.H., Howarth, R.B., 1994. 'Normal' markets, market imperfections and energy efficiency. Energy Policy 22 (10), 811-818. 
Sarasvathy, S., 2001. Causation and Effectuation: Toward a Theoretical Shift from Economic Inevitability to Entrepreneurial Contingency. Academy of Management Review 26 (2), 243-264.

Sarasvathy, S., Dew. N., Velamuri, S.R., Venkataraman, S., 2003. Three views of entrepreneurial opportunity. In: Acs, Z.B., Audretsch, D.B. (Eds.), Handbook of Entrepreneurship Research - An Interdisciplinary Survey and Introduction. Springer, New York, NY, pp. 141-160.

Schaltegger, S., 2002. A framework for ecopreneurship. Leading bioneers and environmental managers to ecopreneurship. Greener Management International $38,45-58$.

Schaper, M., ed., 2005. Making ecopreneurs: Developing sustainable entrepreneurship. Aldershot, Ashgate, UK.

Schlange, L.E., 2006. What drives sustainable entrepreneurs? Paper presented at the Applied Business and Entrepreneurship Association International Conference, Kona, 16-20 November 2006.

Shane, S., 2000. Prior knowledge and the discovery of entrepreneurial opportunities. Organization Science 11 (4), 448-69.

Shane, S., Venkataraman, S., 2000. The promise of entrepreneurship as a field of research. Academy of Management Review 25 (1), 217-226.

Simon, H.A., 1956. Rational choice and the structure of the environment. Psychological Review 63 (2), 129-138.

Souitaris, V., Zerbinati, S., Al-Laham, A., 2007. Do entrepreneurship programmes raise entrepreneurial intention of science and engineering students? The effect of learning, inspiration and resources. Journal of Business Venturing 22, 566-591.

Spence, M., Boubaker Gherib, J.B., Ondoua Biwolé, V., 2008. A framework of SME's strategic involvement in sustainable development. In: Sharma, S. Starik, M., Wüstenhagen, R., Hamschmidt, J. (Eds.), Advances on Research in Corporate Sustainability. Edward Elgar, Boston, MA, pp. 49-70.

Staber, U., 1997. An ecological perspective on entrepreneurship in industrial districts. Entrepreneurship and Regional Development 24 (1), 37-48.

Starr, J.A., Macmillan, I.A., 1990. Resource cooptation via social contracting: Resource acquisition strategies for new ventures. Strategic Management Journal 11, 7992.

Stewart, W.H., Roth, P.L., 2001. Risk propensity differences between entrepreneurs and managers: A meta-analytic review. Journal of Applied Psychology 86, 145153. 
Stinchcombe, A.L., 1965. Social structure and organizations. In March, J.G. (Ed.), Handbook of organizations. Rand McNally, Chicago, IL, pp. 142-193.

Suchman, M.C., 1995. Managing Legitimacy: Strategic and Institutional Approaches. Academy of Management Review 20 (3), 571-610.

Taylor, W.G.K., 1989a. The Kirton adaption-innovation inventory: a re-examination of the factor structure. Journal of Organizational Behavior 10 (4), 297-307.

Taylor, W.G.K., 1989b. The Kirton adaption-innovation inventory: Should the sub-scales be orthogonal? Personality and Individual Differences 10 (9), 921-929.

Tilley, F., 1999. The Gap Between The Environmental Attitudes and The Environmental Behaviour of Small Firms. Business Strategy and the Environment 8 (4), 238248.

Venkataraman, S., 1997. The distinctive domain of entrepreneurship research: an editors' perspective. In: Katz, J., Brockhaus, J. (Eds.), Advances in entrepreneurship, firm emergence, and growth. Springer, New York, NY, pp. 141-160.

Walley, E., Taylor, D., 2002. Opportunists, champions, mavericks? A typology of green entrepreneurs. Greener Management International 38, 31-35.

Williamson, D., Lynch-Wood, G., Ramsay, J., 2006. Drivers of Environmental Behaviour in Manufacturing SME and the Implications for CSR. Journal of Business Ethics 67 (3), 317-330.

Willis, K.G., 1989. Option Value and Non-user Benefits of Wildlife Conservation. Journal of Rural Studies 5, 245-256.

World Commission on Environment and Development, 1987. Our common future. Oxford University Press, Oxford, UK.

Zahra, S.A., Rawhouser, H.N., Bhawe, N. Neubaum, D.O., Hayton, J.C., 2008. Globalization of Social Entrepreneurship Opportunities. Strategic Entrepreneurship Journal 2 (2), 117-131.

Zahra, S.A., Gedajlovic, E., Neubaum, D.O., Shulman, J.M., 2009. A typology of social entrepreneurs: Motives, search processes and ethical challenges. Journal of Business Venturing 24 (5), 519-532.

Zimmerman, M., Zeitz, G.J., 2002.Beyond survival: Achieving new venture growth by building legitimacy. Academy of Management Review 27 (3), 414-431. 
Figure 1

The Effect of Business Experience on the Relationship of Sustainability Orientation and Entrepreneurial Intention

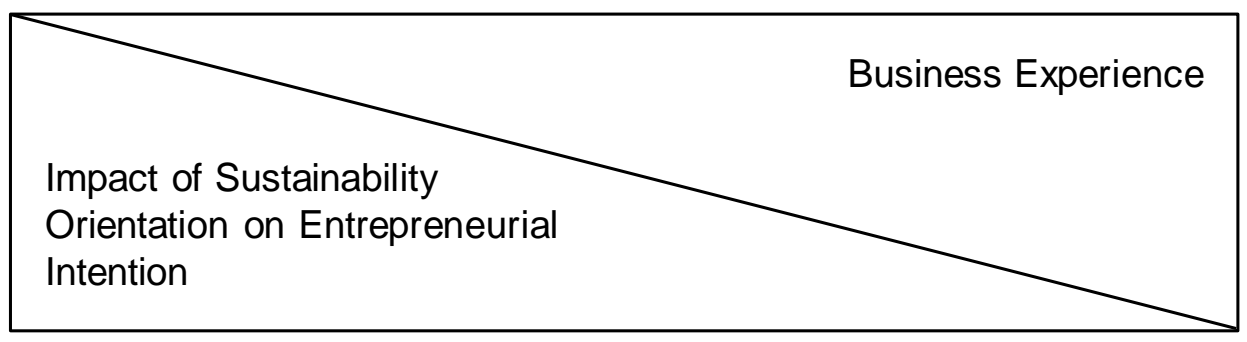


Table 1

Descriptive statistics and correlations $(\mathrm{N}=712)$

\begin{tabular}{|c|c|c|c|c|c|c|c|c|c|c|c|c|c|c|c|c|}
\hline \multicolumn{2}{|c|}{ Variables } & \multirow{2}{*}{$\begin{array}{l}\text { Mean } \\
1.386\end{array}$} & \multirow{2}{*}{$\begin{array}{l}\text { Std. } \\
\text { Dev. } \\
0.487\end{array}$} & \multirow{2}{*}{$\begin{array}{l}\text { Min. } \\
1\end{array}$} & \multirow{2}{*}{$\begin{array}{l}\text { Max. } \\
2\end{array}$} & \multirow[t]{2}{*}{1} & \multirow[t]{2}{*}{2} & \multirow[t]{2}{*}{3} & \multirow[t]{2}{*}{4} & \multirow[t]{2}{*}{5} & \multirow[t]{2}{*}{6} & \multirow[t]{2}{*}{7} & \multirow[t]{2}{*}{8} & \multirow[t]{2}{*}{9} & \multirow[t]{2}{*}{10} & \multirow{2}{*}{$\begin{array}{l}\text { VIF } \\
1.40\end{array}$} \\
\hline 1 & Gender & & & & & & & & & & & & & & & \\
\hline 2 & Age & 23.770 & 5.766 & 17 & 48 & -0.249 & & & & & & & & & & 1.84 \\
\hline 3 & Studies abroad & 0.177 & 0.382 & 0 & 1 & -0.116 & 0.037 & & & & & & & & & 1.50 \\
\hline 4 & $\begin{array}{l}\text { Placement } \\
\text { abroad }\end{array}$ & 0.182 & 0.386 & 0 & 1 & 0.063 & 0.108 & -0.128 & & & & & & & & 1.27 \\
\hline 5 & $\begin{array}{l}\text { Vocational } \\
\text { training }\end{array}$ & 1.757 & 0.429 & 1 & 2 & 0.109 & 0.185 & -0.063 & 0.297 & & & & & & & 1.29 \\
\hline 6 & $\begin{array}{l}\text { Parents self- } \\
\text { employed }\end{array}$ & 0.336 & 0.473 & 0 & 1 & 0.071 & -0.041 & -0.013 & 0.162 & 0.138 & & & & & & 1.17 \\
\hline 7 & $\begin{array}{l}\text { Sustainability } \\
\text { orientation }\end{array}$ & 3.363 & 1.014 & 1 & 5 & -0.296 & 0.276 & 0.383 & -0.240 & -0.155 & -0.103 & & & & & 2.92 \\
\hline 8 & $\begin{array}{l}\text { Propensity to } \\
\text { innovate }\end{array}$ & 3.614 & 0.746 & 1 & 5 & -0.097 & 0.147 & -0.078 & 0.055 & 0.039 & 0.038 & 0.149 & & & & 1.57 \\
\hline 9 & $\begin{array}{l}\text { Attitudes to } \\
\text { entrepreneurship }\end{array}$ & 2.868 & 0.864 & 1 & 5 & -0.095 & 0.077 & 0.007 & 0.228 & 0.242 & 0.230 & -0.123 & 0.117 & & & 1.39 \\
\hline 10 & $\begin{array}{l}\text { Perceived } \\
\text { support }\end{array}$ & 3.073 & 0.623 & 1 & 5 & -0.033 & -0.093 & 0.200 & 0.033 & -0.058 & 0.055 & 0.045 & 0.027 & 0.128 & & 1.17 \\
\hline 11 & $\begin{array}{l}\text { Perceived } \\
\text { barriers }\end{array}$ & 3.368 & 0.703 & 1 & 5 & 0.046 & 0.033 & 0.021 & -0.034 & 0.069 & -0.044 & -0.011 & 0.097 & 0.001 & -0.070 & 1.16 \\
\hline
\end{tabular}

Note: Correlations with an absolute value greater than 0.05 are significant at $p<0.05$; associations between categorical variables are calculated using Cramer's V. 
Table 2

Distribution of dependent variable

\begin{tabular}{c|ccc|c}
\hline $\begin{array}{l}\text { Response to "I intend } \\
\text { to become self- } \\
\text { employed in the next } \\
\text { five years" }\end{array}$ & $\begin{array}{c}\text { Science and } \\
\text { Engineering Stu- } \\
\text { dents total (\%) }\end{array}$ & $\begin{array}{c}\text { Business Stu- } \\
\text { dents total (\%) }\end{array}$ & $\begin{array}{c}\text { Science and } \\
\text { Engineering } \\
\text { Alumni total (\%) }\end{array}$ & $\Sigma$ (\%) \\
\hline I do not agree at all & $11.8 \%$ & $22.0 \%$ & $25.6 \%$ & $12.8 \%$ \\
I largely disagree & $29.1 \%$ & $22.3 \%$ & $32.8 \%$ & $27.1 \%$ \\
I cannot say yet & $43.5 \%$ & $25.9 \%$ & $23.2 \%$ & $33.3 \%$ \\
I largely agree & $10.2 \%$ & $25.2 \%$ & $5.6 \%$ & $15.0 \%$ \\
I absolutely agree & $5.4 \%$ & $18.6 \%$ & $12.8 \%$ & $11.8 \%$ \\
Total & 313 & 274 & 125 & 712 \\
in \% & $44.0 \%$ & $38.5 \%$ & $17.5 \%$ & $100 \%$ \\
\hline
\end{tabular}

Note: percentage figures do not always up to exactly 100 per cent due to rounding of decimals to one digit. 
Table 3

Coefficient estimates for ordered probit models

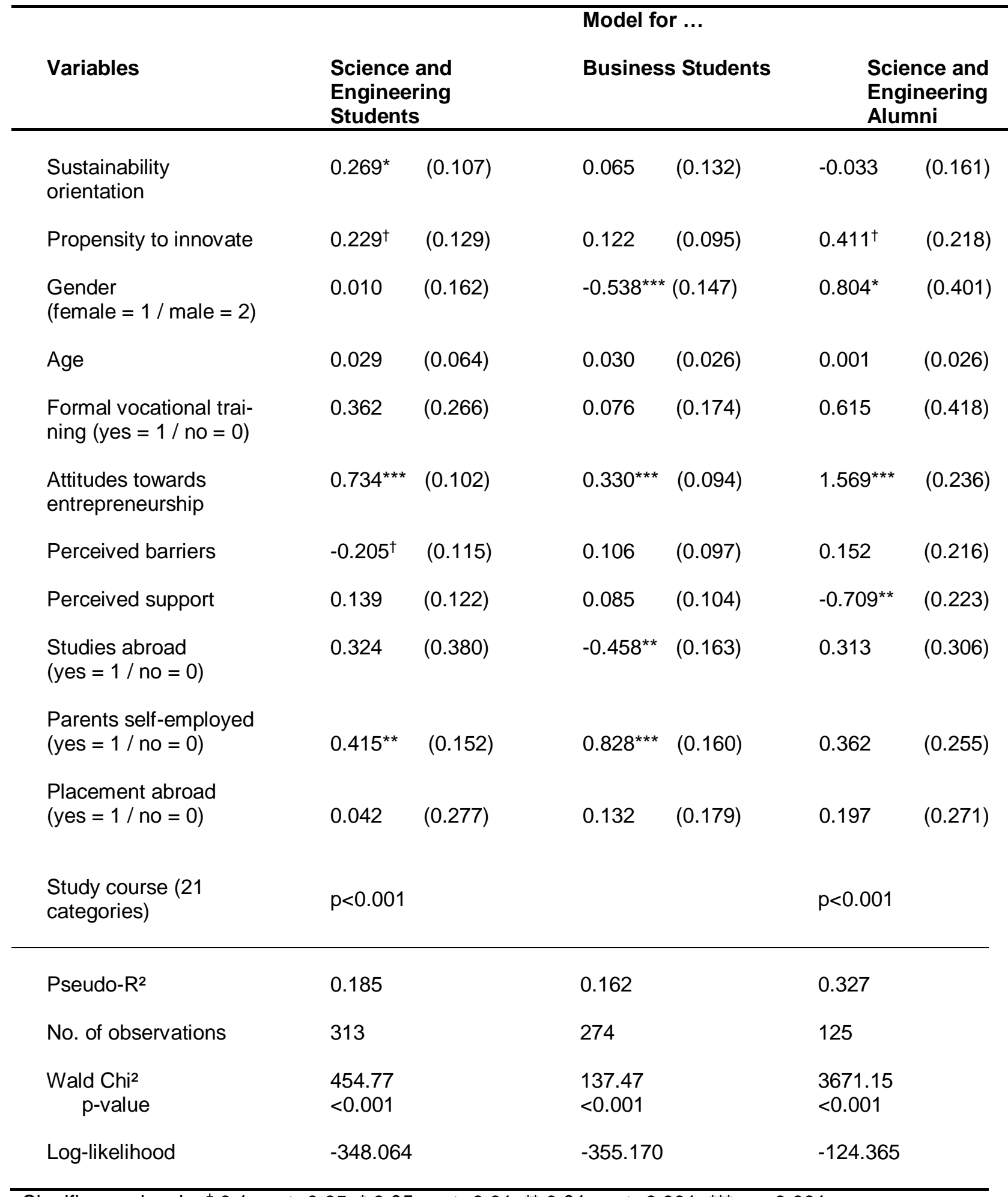

Significance levels: ${ }^{\dagger} 0.1>p \geq 0.05 ;{ }^{*} 0.05>p \geq 0.01 ;{ }^{* \star} 0.01>p \geq 0.001 ;{ }^{* * *} p<0.001$

Note: Heteroskedasticity-robust standard errors in parentheses 